\title{
THE ROLE OF A SUBSIDIARY WITHIN THE VALUE CHAIN OF AN MNE - A STRUCTURAL MODEL DEVELOPMENT
}

A growing number of foreign subsidiaries nowadays specialize in relatively narrow sets of activities in the multinational enterprise (MNE) value chain and perform different roles in it. The scientific problems addressed in this paper are the potential determinants of the roles that the foreign subsidiaries fulfill in the value chains of MNEs. An in-depth analysis of a subsidiary role within the value chain of the MNE is required to recognize exactly how its potential internal and external determinants matter to the subsidiary and the whole MNE, and understand by what means the specific role can be given to or earned by affiliates in the company. The main cognitive goal of the paper is the identification of the relations which may be observed between the factors indicating the subsidiary role in the value chain of an MNE. The fulfillment of this aim requires the development of a theoretical framework that will present the hypothetical relations between the potential variables, and - since the potential variables are latent - a presentation of the variables' indicators. While aiming at the accomplishment of this goal, the author uses secondary sources of information encompassing mainly the international business literature, and uses deductive reasoning.

Keywords: subsidiary role, subsidiary evolution, MNE, multinational enterprises, subsidiary, value chain.

DOI: $10.15611 /$ aoe.2019.1.17

\section{INTRODUCTION}

A multinational enterprise (MNE) can be viewed as a private institution that organizes, through employment contracts, interdependencies between individuals located in more than one country (Hennart 2009). To be able to operate in such a way, an MNE in extending itself over borders, makes foreign direct investment (FDI). Therefore, in its simplest terms, a multinational enterprise is a company that has at least one foreign subsidiary (OECD 2008), which means that in no less than one location an MNE uses offshoring as a relocation form within its value chain. While MNEs are generating structures that are highly differentiated, at the same

\footnotetext{
* Department of International Competitiveness, Poznań University of Economics and Business.
} 
time they reveal noticeable global organizational properties (Lomi, Larsen 1996; Lomi, Pettison 2006). The scientific problems undertaken in this paper are the potential determinants of the roles that the foreign subsidiaries fulfill in the value chains of MNEs. The main cognitive goal of the paper is the identification of the relations, which may be observed between the factors indicating the roles that the foreign subsidiaries had been fulfilling in the value chains of MNEs. The fulfillment of this aim requires the development of a theoretical framework which will present the hypothetical relations between the potential variables, since the potential variables are latent, and multidimensional concepts - a presentation of the variables' indicators. While aiming at the accomplishment of the goal, the author uses secondary sources of information, encompassing mainly the international business literature.

The idea that subsidiaries may differ in terms of the scope of their operations, the extent of responsibilities, the importance of the markets they serve and their level of competence, is well established in the literature and has led to the execution of a growing number of studies concerning the categorization of a subsidiaries role (Birkinshaw, Pedersen 2009). However, although the issue of discrepancies in regard to subsidiary roles across value chain activities has recently gained some attention (see e.g. Rugman et al. 2011), so far it has not been thoroughly discussed or operationalized. To the best of the author's knowledge, an attempt to create a model dealing with the determinants of the subsidiary role within the value chain of an MNE is unique.

An in-depth analysis of a subsidiary's role within the value chain of an MNE is required to recognize exactly how its potential internal and external determinants matter to the subsidiary and the whole MNE, and understand by what means the specific role can be given to or earned by affiliates in the company. Besides the academic interest in this research area, the issues related to the subsidiary's role within the value chain of an MNE should be especially important for two groups of interests which are subsidiary managers and market regulators (national governments).

The model, together with its empirical verifications, should allow managers to decide if a particular set of actions and course of development are worth maintaining, thus facilitating decisions about whether or not the given factors even matter, and if they do, which of them seem most likely to contribute to the desired direction of change. It may also help to indicate whether and, if so, which factors are worth highlighting within the 
communication process with the HQ. On the other hand, governments of many countries are interested in attracting foreign capital to their economies, especially in the form of foreign direct investments. This capital allows the host countries to benefit from MNE spillover effects that may encompass inter alia the upgrading of the local supplier base, the productivity improvement for the local human capital, the increase in sophistication of local demand and better customer service, and the attraction of follow-up investments (Nachum 2000; Rugman, Verbeke 2009). The initial further investments also contribute to the development of the economy and increase the probability of higher budget inflows resulting from corporate income tax and a lower unemployment rate in the future.

At the same time, the attractiveness of the host country perceived by the MNE may change, as well as the factors creating this attractiveness in the first place. Taking this perspective, the governments should be interested in attracting subsidiaries with future potential for the development of their roles, or affiliates fulfilling as advanced roles as possible, for two reasons. Firstly, over time the primary host country's advantages may no longer be valid for the MNE, leading the decision-makers to either relocate the subsidiary or change the affiliate's role within its value chain. The market regulators may aim at being actively involved in supporting the creation of conditions appropriate for the desired directions of change. In such a case, knowledge regarding the bundles of factors that seem most likely to contribute to the intended direction of transformation is required. Secondly, the gains for the host economy resulting from the fulfillment of the more advanced roles in the value chain of the MNE, are greater than the ones resulting from the execution of less advanced roles.

Taken together, the presented model stands out as a complex and multidimensional research workshop that draws its roots from distinct, but at the same time interlinked, research areas such as the activity-based view of a firm, the resource-based view of a firm, the network model of an MNE, the resource dependency theory and the theories of industrial organization. While trying to meet this challenge, in the following parts of the paper the author presents basic literature findings concerning subsidiary role determinants and studies related to this research area, develops the model and submit proposals for variables operationalization and provides closing remarks. 


\section{LITERATURE OVERVIEW}

The management of foreign subsidiaries has become a distinctive field of investigation for international business scholars (Manolopoulos 2008). In the opinion of the earliest international business researchers of headquarterssubsidiary relations, an MNE is organized as a hierarchy controlling its subsidiaries (Brand, Hulbert 1977; Picard 1980; Cray 1984), where the latter are in a position of complete subordination towards the headquarters (HQ). Therefore, the relationship between the HQ and the subsidiaries are essentially determined by the former, $\mathrm{a}$ is the role fulfilled by a subsidiary in an MNE's value chain (White, Poynter 1984; Bartlett, Ghoshal 1986; Ghoshal, Nohria 1989). However, since the mid-1980s there has been a shift to the notion, where MNEs are perceived as inter-organizational networks geographically dispersed and differentiated, but at the same time interdependent units (Crookell 1986; D'Cruz 1986). This approach was more formally developed in the 1990s and later into a network model of an MNE (Ghoshal, Bartlett 1991; Nohria, Ghoshal 1994; Rugman, Verbeke 2003). From this perspective an MNE can be seen as a federation where the headquarters and the subsidiaries are involved in a perpetual bargaining process (Asakawa 2001; Mudambi, Navarra 2004; Andersson et al. 2007), and the subsidiary may possess potential and considerable latitude to formulate a strategy and make autonomous decisions (Birkinshaw 1997; Taggart 1997; Taggart 1998; Birkinshaw 2000; Birkinshaw et al. 2001; Rugman, Verbeke 2001; Cantwell, Mudambi 2005; Ambos et al. 2010). The change of a subsidiary's role within the MNE may be driven by decisions made by the parent company management and/or constitute the effect of subsidiary managers' initiative (Birkinshaw 1997; Birkinshaw et al. 1998; Frost et al. 2002).

At the same time, the observation of the changes happening within the external environment (i.e. regional economic integration) in relation to MNEs' operations has led international business scholars to notice that these economic entities adjust their actions and strategies to changes in the environmental conditions (Kindleberger 1966; Dunning, Robson 1988; Yamawaki 1993; Ford, Strange 1999). According to Ghoshal and Nohria (1997) this adjustment takes place through the integration of each subsidiary's strategy to certain local conditions, while taking into consideration the resource configuration of the headquarters. Therefore, the model developed by Birkinshaw and Hood (1998) took into consideration three drivers of a subsidiary's evolution - HQ management, subsidiary 


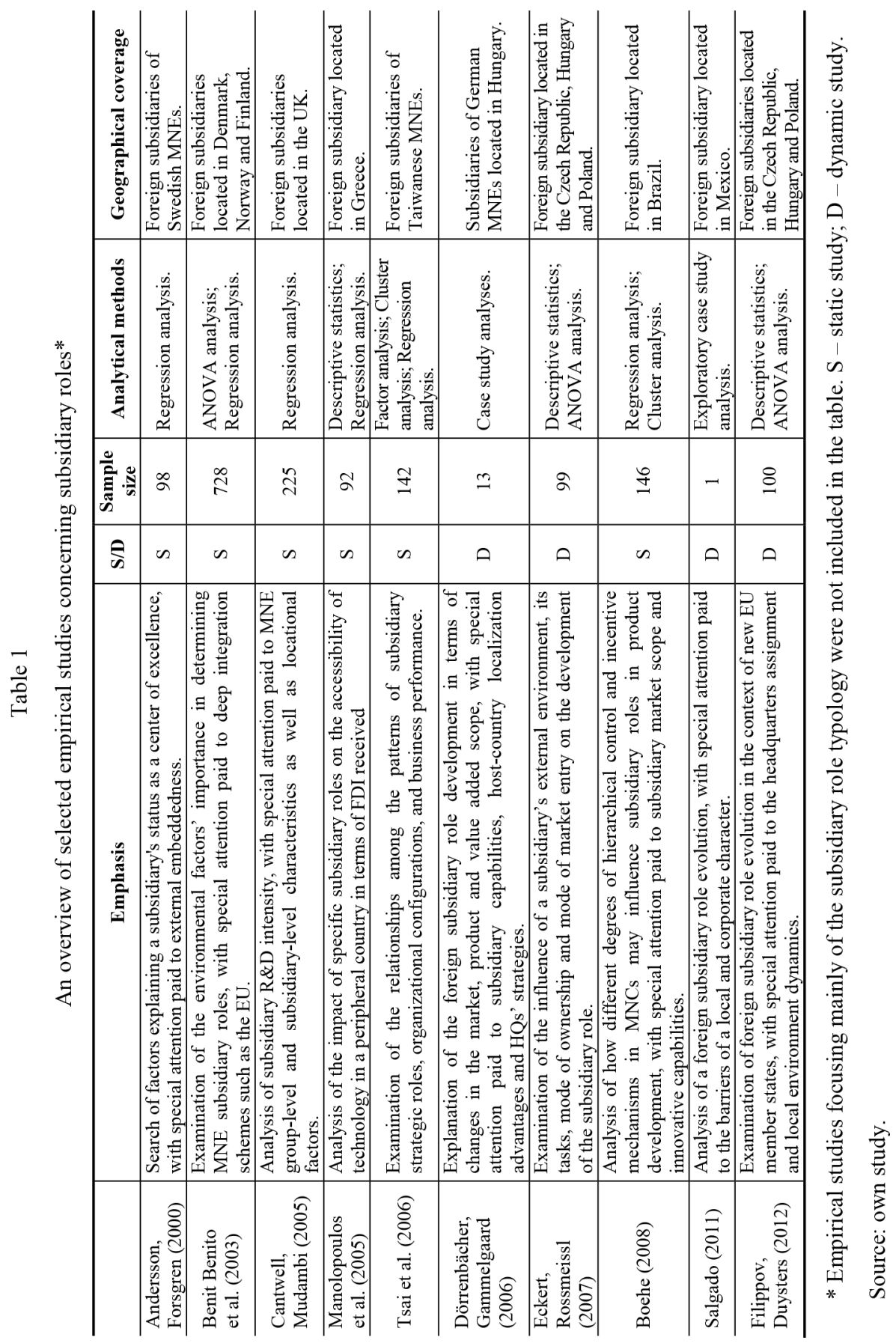


management and local environment dynamics. Such an approach was supported among others by Dörrenbächer and Gammelgaard (2006), Benito and Narula (2007), Filippaios and Papanastossiou (2008).

Table 1 presents a juxtaposition of the empirical studies referring directly to the determinants of foreign subsidiary's roles, while taking into consideration the emphasis of the study, the sample size used, the character of the study (static/dynamic), the analytical methods used and the broadly understood geographic coverage of the study. Researchers focusing on subsidiary role determinants support their reasoning with findings of a qualitative and quantitative character. While doing so they use such analytical methods as regression, ANOVA and cluster analyses or case study analysis. Surprisingly, when examining subsidiary role determinants, international business scholars have not been using structural equation modeling, though this solution seems natural since the potential existence of structural interrelations between the determinants (factors specific for HQ, subsidiary, and environment) and its use in reference to other studies related to foreign subsidiaries; see e.g. Forsgren et al. (1999); Andersson et al. (2002); Andersson et al. (2007). This constitutes a research gap that should be filled.

\section{THE MODEL'S DEVELOPMENT}

In the paper the role of a subsidiary is understood as the sum of its functions, tasks and areas of responsibilities (Rank 2000, p. 4). Therefore, it is clear that many variables may influence its development. As mentioned above, in regard to the sources of subsidiary role determinants in the literature, three approaches dominate (HQ, subsidiary, environment) (Dörrenbächer, Gammelgaard 2006; Filippov, Duysters 2012), which have been subsequently developed and expanded. Within the listed groups of factors more specific subgroups may be customized to emphasize of a particular study. In this paper the following groups are applied:

- The HQ's involvement;

- A subsidiary's strategic maturity;

- Environment-related factors.

This remains in line with the approach adapted by among others: Birkinshaw and Hood (1998), Dörrenbächer and Gammelgaard (2006), Harzing and Noorderhaven (2006), Benito and Narula (2007), Filippaios and Papanastossiou (2008). A central question in reference to the presented issue of subsidiary role determinants is the understanding and operationalization of the affiliate role. 


\subsection{A subsidiary role in an MNE value chain}

As mentioned before, in this paper the role of a subsidiary in an MNE value chain is understood as the sum of its functions, tasks and areas of responsibilities (Rank 2000, p. 4). Therefore, the variable has a latent multidimensional character which requires further operationalization.

As evidenced in the literature, a variation in the subsidiary role may be reflected by the subsidiary's size (Holm, Pedersen 2000). The size of the foreign subsidiary may be expressed, among others, by the number of employees and value of turnover. In fact, these two indicators are complementary, however an increase in their nominal values may be related to the speed of growth of the whole MNE. Therefore, it is suggested that such indicators take relative forms. Additionally, the dimension of its scope may be narrowed to focus on specific activities and expertise built within selected areas (Surlemont 1998). To check for areas of operations, an indicator concerning the number of main activities generating turnover should be provided.

An additional issue that should be included is the range of main activities executed by the subsidiary. In this context one could take into consideration the national, regional and global mandate for each activity under analysis. The subsidiary's geographic range can affect both the development and use of capabilities (Enright, Subramanian 2007).

At the same time there may be variations in the subsidiary role that reflect the differences, for example, in its involvement in export/import activities (Holm, Pedersen 2000). To control for the extent to which subsidiaries operate beyond the local market several indicators may be taken into account: the number of foreign countries served, export intensity and import intensity. Moreover, to control for the extent to which subsidiaries depend on MNEs with regard to their operations, the ratio of purchases and sales within MNEs may be observed, while the advancement of the operations performed by the foreign subsidiary may find its reflection in their complexity and level of generated added value.

Therefore, based on the literature studies, it was concluded that the role of a subsidiary in an MNE value chain could be reflected by indicators related, among others, to: size of the subsidiary, its areas of operation, scope of its international operations and dependence on the MNE, and level of advancement of its operations. Table 2 presents the potential indicators of thus understood subsidiary's role, while taking into consideration the existing accumulation of knowledge. At this point it is worth highlighting 
Table 2

Subsidiary role in the MNE's value chain (latent variable) potential indicators

\begin{tabular}{|c|c|}
\hline Indicator & Operationalization \\
\hline \multicolumn{2}{|l|}{ Size } \\
\hline $\begin{array}{l}\text { Relative size } \\
\text { of employment }\end{array}$ & $\begin{array}{l}\text { Relative size of employment }=a_{1} / A_{1} \text {, where } a_{1} \text { is the total number of } \\
\text { employees in the subsidiary and } A_{1} \text { is the total number of employees in the } \\
\text { whole MNE. Therefore, this indicator takes into account the share of the } \\
\text { subsidiary's employees within the whole MNE. }\end{array}$ \\
\hline $\begin{array}{l}\text { Relative value } \\
\text { of turnover }\end{array}$ & $\begin{array}{l}\text { Relative value of turnover }=b_{1} / B_{1} \text {, where } b_{1} \text { will be the total value of the } \\
\text { turnover generated by the subsidiary and } B_{1} \text { will be the total value of the } \\
\text { turnover generated by the whole MNE. Therefore, this indicator will take into } \\
\text { account the share of the subsidiary's turnover within the whole MNE. }\end{array}$ \\
\hline \multicolumn{2}{|l|}{ Areas of operations } \\
\hline $\begin{array}{l}\text { Number of main } \\
\text { activities }\end{array}$ & $\begin{array}{l}\text { Number of main activities type }=\sum \mathrm{c}_{\mathrm{i}} \text {, where } \mathrm{c}_{\mathrm{i}} \text { is any given area of turnover } \\
\text { generating operations according to a provided list. Areas may be listed based } \\
\text { on Porter's concept of the value chain (1985): research and development, } \\
\text { production of goods or services, marketing/sales, logistics/distribution, } \\
\text { purchasing, human resource management, service, infrastructure. In such a } \\
\text { case value of the indicator equals a number from } 0 \text { to } 8 \text { (if outbound and } \\
\text { inbound logistics is unified in one activity - logistics). }\end{array}$ \\
\hline Scope of main activities & $\begin{array}{l}\text { Indication of national, regional or global mandate for each considered } \\
\text { activity. }\end{array}$ \\
\hline \multicolumn{2}{|l|}{$\begin{array}{l}\text { International } \\
\text { operations }\end{array}$} \\
\hline $\begin{array}{l}\text { Number of foreign } \\
\text { countries served }\end{array}$ & $\begin{array}{l}\text { Number of foreign countries served }=\sum d_{i} \text {, where } d_{i} \text { will be any given foreign } \\
\text { country i served by the subsidiary. Therefore, the indicators will simply total } \\
\text { the number of foreign countries served. }\end{array}$ \\
\hline Import intensity & $\begin{array}{l}\text { To control for the subsidiary dependence on imports, the share of imports in } \\
\text { total purchase may be taken into account. Therefore, the value would range } \\
\text { from } 0 \text { to } 100 \% \text {. }\end{array}$ \\
\hline Export intensity & $\begin{array}{l}\text { To control for the subsidiary dependence on exports, the share of export in } \\
\text { total sales may be taken into account. Therefore, the value would range from } \\
0 \text { to } 100 \% \text {. }\end{array}$ \\
\hline \multicolumn{2}{|l|}{ Dependence on MNE } \\
\hline $\begin{array}{l}\text { Share of internal } \\
\text { purchases }\end{array}$ & $\begin{array}{l}\text { The indicator may be expressed by the share of the total purchases bought } \\
\text { from the parent company or sister companies within the MNE. Therefore, the } \\
\text { value would range from } 0 \text { to } 100 \% \text {. }\end{array}$ \\
\hline Share of internal sales & $\begin{array}{l}\text { The share of internal sales may be expressed by the share of the total sales } \\
\text { sold to the parent company or sister companies within the MNE. Therefore, } \\
\text { the value would range from } 0 \text { to } 100 \% \text {. }\end{array}$ \\
\hline \multicolumn{2}{|l|}{$\begin{array}{l}\text { Advancement } \\
\text { of operations }\end{array}$} \\
\hline $\begin{array}{l}\text { Complexity level of the } \\
\text { performed tasks }\end{array}$ & $\begin{array}{l}\text { This indicator may be expressed on a 7-point Likert-type scale as } \\
\text { recommended by Cox (1980), where } 1=\text { very low level of complexity of } \\
\text { activities performed by the subsidiary and } 7=\text { very high level of complexity. }\end{array}$ \\
\hline Level of added value & $\begin{array}{l}\text { In some studies, value added indicators are used in the same way as the } \\
\text { earlier proposed indicator of areas of operations; see Hogenbirk and } \\
\text { Kranenburg (2006). However, it may also be expressed on a } 7 \text {-point Likert- } \\
\text { type scale, where } 1=\text { very low level of added value generated by the } \\
\text { subsidiary and } 7=\text { very high level of added value. }\end{array}$ \\
\hline
\end{tabular}

Source: own study. 
that all the mentioned indicators may change over time. Such changes could reflect the evolution of the subsidiary role in an MNE value chain. Since the described variable is multidimensional, changes with regard to its single indicator might be less visible for the whole variable, than the simultaneous alternation of at least a few indicators. Nevertheless, depending on the direction of change, such variations can indicate either the advancement or reduction of the subsidiary role in an MNE value chain. The advancement of such a role would be reflected, for example, by the increase in the relative size of employment and value of turnover, the rise in the number of main activities conducted by the subsidiary and their scope, the increase of the number of foreign countries served and export intensity, etc. Similarly, the reduction of the subsidiary role in an MNE value chain would be revealed by the decrease of the already mentioned indicators. ${ }^{1}$

\subsection{The subsidiary role within an MNE value chain and the HQ's involvement}

The shift in understanding an MNE as an hierarchical organization, controlling and subordinating its subsidiaries (Brand, Hulbert 1977; Picard 1980; Cray 1984), to seeing it as an inter-related network of geographically dispersed and differentiated units (Crookell 1986; D'Cruz 1986; Ghoshal, Bartlett 1991; Nohria, Ghoshal 1994; Rugman, Verbeke 2003; Andersson et al. 2007), has been visible in the international business literature for some decades. However, this does not mean that the head office itself, and its influence exerted on subsidiaries, are no longer valid (Zhou, Frost 2005). The HQ's role has rather evolved into an integrator and coordinator of internationally dispersed network units. The parent company still exerts an influence on the subsidiary through the use of control and the allocation of such resources as the formation of new plants, capital investments, technology transfer etc. (Birkinshaw, Hood 1997). Many researchers have emphasized the interaction between decision-making decentralization (autonomy level) and the role fulfilled by a foreign subsidiary; see e.g. Bartlett and Ghoshal (1989); Martinez and Jarillo (1990); Gupta and Govindarajan (1991); Nobel and Birkinshaw (1998); Ambos and Schlegelmilch (2007). The autonomy level is often operationalized as a decision right granted by the parent company, whilst the granted decisionmaking rights may concern different areas of decisions.

\footnotetext{
1 The author of the paper is aware that the interpretation of the changes related to the indicators of a subsidiary's dependence on an MNE might create some challenges when interpreting a subsidiary role in an MNE value chain.
} 
Additionally, the existence of a foreign subsidiary always requires the allocation of certain resources and capabilities by the parent company. Since these resources and capabilities may be perceived as a competitive potential of the subsidiary, it is obvious that its development is influenced by the HQ. Therefore, the HQ may directly influence the subsidiary's competitive potential development process by the scale of flows of widely understood resources and capabilities. A decrease in these flows may hinder the development of the subsidiary, while an increase may further aid its progress. When referring to these flows, besides considering the division between resources and capabilities, it may also be important to differentiate between their size and sufficiency.

In some cases subsidiaries are requested to actively engage in the development of their operations and explore procedures that would increase the efficiency of the whole MNE (Crookel, Morrison 1990; Birkinshaw 1996). However, even if a subsidiary possesses superior resources, it still must be recognized and acknowledged by the HQ in order to qualify the subsidiary for a new mandate (Prahalad, Doz 1981). This is important as the

Table 3

HQ's involvement (latent variable) potential indicators

\begin{tabular}{l|l}
\hline \multicolumn{1}{c|}{ Indicator } & \multicolumn{1}{c}{ Operationalization } \\
\hline Autonomy level & $\begin{array}{l}\text { Following examples of other international business studies indicators } \\
\text { concerning autonomy level may relate to launching new products, } \\
\text { entering new markets, choice of suppliers. Respondents may be } \\
\text { asked to give answers to such questions on a 5-point Likert-type } \\
\text { scale, where 1=the headquarters decides alone and 5=the subsidiary } \\
\text { decides alone. }\end{array}$ \\
\hline $\begin{array}{l}\text { Support in terms } \\
\text { of competitive } \\
\text { potential } \\
\text { development }\end{array}$ & $\begin{array}{l}\text { The respondents may be requested to state their opinions on a 7-point } \\
\text { rikert-type scale, where 1=strongly disagree and 7=strongly agree, } \\
\text { refering to the following sentences: the amount of resources } \\
\text { provided by the parent company is very big; the amount of resources } \\
\text { development of subsidiary capabilities provided by the parent } \\
\text { company is significant; the support in development of subsidiary } \\
\text { capabilities provided by the parent company is fully sufficient. }\end{array}$ \\
\hline $\begin{array}{l}\text { Appraisal of } \\
\text { subsidiary aims } \\
\text { fulfillment/actions } \\
\text { recognition }\end{array}$ & $\begin{array}{l}\text { The respondents may be asked to state their opinions on a 7-point } \\
\text { Likert-type scale, where 1=strongly disagree and 7=strongly agree, } \\
\text { referring to the following sentences: the HQ's appraisal of the } \\
\text { subsidiary aims fulfillment is very high; the HQ's appraisal of the } \\
\text { subsidiary's capabilities is very high; HQ's appraisal of the } \\
\text { subsidiary's resources is very high. }\end{array}$ \\
\hline
\end{tabular}

Source: own study. 
parent company is interested in adding value to the whole MNE (Delany 2000), and if it recognizes such an opportunity in a foreign subsidiary it may decide to support its development, change its autonomy level or simply change the role that it fulfills in an MNE value chain. Therefore, one of the indicators to be taken into account should be the appraisal of the fulfillment of subsidiary's aims and its recognition, together with the acknowledgement of the subsidiary's resources and capabilities.

In the paper, HQ-related factors referring to resource allocation decisions, control exerted over subsidiaries and the acknowledgement of subsidiary actions/results are gathered into a latent variable known as the HQ's involvement. Table 3 presents a list of indicators for the HQ's involvement variable.

All the mentioned above factors may have a considerable influence on a foreign subsidiary and its development possibilities, in particular its resources and capabilities development and the evolution of the role fulfilled in an MNE value chain. Therefore, the first hypothesis is:

Hypothesis 1: The HQ's involvement is positively related to the advancement of a subsidiary role in an MNE value chain.

\subsection{A subsidiary role within an MNE value chain and the subsidiary's strategic maturity}

Enterprises are heterogeneous in regard to their resources (Penrose 1959). This heterogeneity is also valid for foreign subsidiaries, because an MNE can be perceived as a bundle of geographically dispersed units possessing distinctive resources (Madhok 1997). Moreover, according to the assumptions of the resource-based theory, the features of the resources possessed by a company are crucial to its competitiveness (Wernerfelt 1984; Prahalad, Hamel 1990; Barney 1991). In relation to a foreign subsidiary it can be assumed that the asymmetry with regard to resource distribution may be reflected in the subsidiary's results, and consequently in its development scope (Amit, Schoemaker 1993). There is some empirical evidence for the existence of a correlation between a subsidiary's level of competence and its role within the MNE (Furu 2001). Additionally, studies by Forsgren and Pedersen (1998), Fratocchi and Holm (1998) and others, highlight the significance of the subsidiary's competitive potential (competence) in the role development process. In the activity-based view of a firm (Porter 1985), the emphasis within the competitive potential is put on actions taken by an enterprise; in the resource-based view of a firm (Wernerfelt 1984; Barney 
1991), attention is focused on company resources. However, it also may be assumed that these approaches are complementary.

Subsidiaries of MNEs are embedded in different local networks (Ghoshal, Bartlett 1991; Ghoshal, Nohria 1997; Forsgren et al. 2000), which results in different exposure to new knowledge, ideas and opportunities (McEvily, Zaheer 1999). From this perspective, the subsidiary's network embeddedness can be looked upon as a strategic resource influencing the operations and results of the subsidiary (Andersson et al. 2002). Additionally, network embeddedness should be treated as a continuous variable rather than as a dichotomy that is either absent or present (Dacin et al. 1999, p. 24), as business networks are assumed to develop over time.

The change in subsidiary role in an MNE value chain may be influenced not only by the subsidiary's capabilities, but also by its initiative (Filippov, Duysters 2012). This is in line with the network model of the MNE, since the position of a subsidiary within their MNE's network may not only be assigned by the parent firm, but also result from independent and innovatory activities undertaken by a subsidiary, as they enable it to develop its own unique resources and expertise locally (Birkinshaw et al. 1998). According to Delany (2000), managing a subsidiary effectively is not simply about carrying out the mandate awarded by the parent company, but rather about fulfilling the current mandate in a superior way and taking strategic initiatives which add new value to the corporation. Bishop and Crookell (1986), Ghoshal (1986) and Birkinshaw (1995), all found evidence that aspects of subsidiary initiative exerted an influence on the role fulfilled by the subsidiary.

In this paper factors such as subsidiary capabilities, resources and initiative, their quantity and quality features taken together reflect the latent variable called a subsidiary's strategic maturity. Table 4 presents a list of indicators for the subsidiary's strategic maturity variable.

While researchers such as Bishop and Crookell (1986), Ghoshal (1986) and Birkinshaw (1995), all found evidence that aspects of the subsidiary's initiative exerted an influence on the role fulfilled by the subsidiary; Birkinshaw and Hood (1997) Birkinshaw et al. (1998), Ambos et al. (2010) results suggest that an improvement of the subsidiary's resources and capabilities makes the subsidiary better equipped to fulfill more advanced roles within the MNE. As a result, there exists the justification for the assumption that the higher level of strategic maturity a foreign subsidiary has, the better bargaining power it possesses, and the higher influence it has on its role fulfilled in an MNE value chain. Thus, the second hypothesis is:

Hypothesis 2: The subsidiary's strategic maturity is positively related to the advancement of a subsidiary role in an MNE value chain. 
Table 4

Subsidiary's strategic maturity (latent variable) potential indicators

\begin{tabular}{|c|c|}
\hline Indicator & Operationalization \\
\hline \multicolumn{2}{|l|}{$\begin{array}{l}\text { Competitive } \\
\text { potential }\end{array}$} \\
\hline Capabilities & $\begin{array}{l}\text { All the capabilities may be evaluated in relation to the areas of operation applied } \\
\text { in the study that generate turnover in the foreign subsidiary. Therefore, there } \\
\text { would be minimum } 1 \text { and maximum } 8 \text { evaluations for one subsidiary. Particular } \\
\text { evaluations would be expressed on a } 7 \text {-point Likert-type scale, where } 1=\text { very } \\
\text { weak side of the foreign subsidiary located in Poland and } 7=\text { very strong side. } \\
\text { Depending on the fit of the data the evaluations could be used as separate } \\
\text { indicators or aggregated into one indicator }=\sum \mathrm{e}_{\mathrm{i}} / \sum \mathrm{c}_{\mathrm{i}} \text {, where } \mathrm{e}_{\mathrm{i}} \text { is a single } \\
\text { evaluation of capabilities in a particular area and } \mathrm{c}_{\mathrm{i}} \text { is an area of operations that } \\
\text { generate turnover in the foreign subsidiary. }\end{array}$ \\
\hline Resources & $\begin{array}{l}\text { The division of resources applied in the study may include financial resources, } \\
\text { human resources, tangible and intangible assets. Therefore, there would be four } \\
\text { evaluations in the case of one subsidiary. Particular evaluations may be } \\
\text { expressed on a } 7 \text {-point Likert-type scale, where } 1=\text { very weak side of the } \\
\text { subsidiary and } 7=\text { very strong side. Depending on the fit of the data, the } \\
\text { evaluations could be used as separate indicators or aggregated into one } \\
\text { indicator }=\sum \mathrm{f}_{\mathrm{i}} / 4 \text {, where } \mathrm{f}_{\mathrm{i}} \text { is a single evaluation of resources available and used in } \\
\text { the subsidiary. }\end{array}$ \\
\hline \multicolumn{2}{|l|}{$\begin{array}{l}\text { Relations with local } \\
\text { suppliers/portfolio } \\
\text { of local suppliers }\end{array}$} \\
\hline Uniqueness of ties & $\begin{array}{l}\text { The indicator refers to the extent the subsidiary uniqueness is caused/supported } \\
\text { by the relations with local suppliers. The indicator may be expressed on a } 7- \\
\text { point Likert-type scale, where } 1=\text { not at all and } 7=\text { very much, while the } \\
\text { respondents may be asked to express their opinion in reference to the statement: } \\
\text { The subsidiary's relations with present suppliers fully support the subsidiary's } \\
\text { uniqueness. }\end{array}$ \\
\hline Needs fulfillment & $\begin{array}{l}\text { The indicator expresses the level of fulfillment of the foreign subsidiary's needs } \\
\text { in relation to the portfolio of local suppliers and therefore, evaluates the } \\
\text { discrepancies between the subsidiary's expectations and reality. Evaluations } \\
\text { may be expressed on a 7-point Likert-type scale, where } 1=\text { strongly disagree and } \\
7=\text { strongly agree, while the respondents may be asked to express their opinion in } \\
\text { reference to the statement: The subsidiary's relations with present suppliers fully } \\
\text { meet our expectations and needs. }\end{array}$ \\
\hline Initiative & $\begin{array}{l}\text { In the paper it is assumed that the initiative may concern four distinct but at the } \\
\text { same time inter-related matters, these are: resources and capabilities, the } \\
\text { presence of subsidiary's offer in geographic markets, the main areas of the } \\
\text { subsidiary's operations and corporate investments. Therefore, in regards to those } \\
\text { four matters, respondents could be asked to evaluate the following } 4 \text { statements: } \\
\text { The subsidiary takes initiative regarding the development of its resources and } \\
\text { capabilities. The subsidiary takes initiative regarding expansion to new } \\
\text { geographic markets. The subsidiary takes initiative regarding new areas of its } \\
\text { operations. The subsidiary takes the initiative regarding new corporate } \\
\text { investments. In reference to those statements the respondents are asked to give } \\
\text { their opinion using a 7-point Likert-type scale, where 1=strongly disagree and } \\
7=\text { strongly agree. }\end{array}$ \\
\hline
\end{tabular}

Source: own study. 


\subsection{The HQ's involvement and the subsidiary's strategic maturity}

As mentioned before, the HQ exerts influence on the subsidiary by the use of control and through the allocation of resources which always require decision making. The decision-making process may still be a subject of discussion and negotiations between the HQ and subsidiaries (Hedlung, Rolander 1990; Taggart 1999; Dörrenbächer, Gammelgaard 2006). While the power of a parent company is acquired by the ownership rights, the strength of a subsidiary in the bargaining process may result from the quality and quantity features of the subsidiary's resources and capabilities (Dörrenbächer, Gammelgaard 2006). These features may result from resources and capabilities allocated by the HQ and/or developed independently by the subsidiary, and thus the HQ may influence the subsidiary's strategic maturity. On the other hand, these features together with favorable environmental conditions may drive the parent company to increase its involvement in the subsidiary. Therefore, an interaction should be occurring between the HQ's involvement level and the subsidiary's strategic maturity level.

The existence of a reciprocal relationship between the MNE units is also assumed by the network model of the MNE (Andersson et al. 2007) and the resource dependency theory (Pfeffer, Slancik 1978). From this perspective, the uniqueness of MNEs is driven by their ability to create rare value by combining resources and activities located in different places in the external and internal environment (Lorenzoni, Baden-Fuller 1995; Andersson, Johanson 1997), while MNEs and their subsidiaries stay dependent on each other in regard to their resources, as they are crucial for MNEs' effectiveness and successes (Pfeffer, Slancik 1978). Therefore, the third hypothesis is:

Hypothesis 3: There is an interaction effect between the HQ's involvement and the subsidiary's strategic maturity when explaining the subsidiary's role in the MNE's value chain.

\subsection{External environment specific factors and a subsidiary role in the value chain of an MNE}

As mentioned before, the decisions and actions related to the development of a particular subsidiary role are made and carried out by the MNE (i.e. headquarters management) and/or the subsidiary itself (managers from the subsidiary). However, in this paper it is also assumed that the actions and decisions of an enterprise may be influenced by external 
environment conditions. This is in line with the general findings of strategic management researchers, e.g. Spanos, Likoukas (2001), Cyrson (2002) and the findings of Benito and Narula (2007) and also Filippaios and Papanastossiou (2008), who during their studies demonstrated that particular environment conditions may influence the development of a foreign subsidiary role. Therefore, the evolution of a subsidiary role may be driven by an external environment and the changes within it.

According to Birkinshaw (1996), external environment indicators should be built on the main elements of Porter's diamond model of national competitiveness (1990). However, the area of inquiry may be also extended to the macro-environment factors. From such a perspective, external environment conditions may be understood as location specific settings related to a macroenvironment and a competitive environment, while the changes might by caused by a one-off event (e.g. joining a regional economic block) or by long-term, gradual changes taking place in reference to a particular market or consumer behavior (i.e. transitions of economies). In the paper the set of indicators related to competitive and macroeconomic conditions is reflected by the latent variable termed as external environment-specific factors. Table 5 presents a list of the potential indicators for the variable.

Table 5

External environment specific factors (latent variable) potential indicators

\begin{tabular}{|c|c|}
\hline Indicator & Operationalization \\
\hline $\begin{array}{l}\text { Competitive } \\
\text { conditions }\end{array}$ & $\begin{array}{l}\text { The respondents may be asked to give their evaluation on a 7-point } \\
\text { Likert-type scale; where } 1=\text { =very unfavorable conditions and } 7=\text { =very } \\
\text { favorable conditions. With reference to the competitive environment, } \\
\text { respondents could be assessing the following factors: Demand; } \\
\text { Competition; Quality of potential suppliers; Availability of potential } \\
\text { suppliers; Prices of potential production factors; Quality of potential } \\
\text { production factors; Availability of potential production factors. }\end{array}$ \\
\hline $\begin{array}{l}\text { General } \\
\text { macroeconomic } \\
\text { conditions }\end{array}$ & $\begin{array}{l}\text { The respondents may be asked to give their evaluation on a } 7 \text {-point } \\
\text { Likert-type scale; where } 1=\text { very unfavorable conditions and } 7=\text { very } \\
\text { favorable conditions. When referring to more general macroeconomic } \\
\text { environment conditions, respondents could be asked to assess inter alia: } \\
\text { Quality of institutional environment; Legal environment; Quality of } \\
\text { infrastructure. }\end{array}$ \\
\hline
\end{tabular}

Source: own study.

In this context, the external environment is linked directly to the issue of host country specific advantages, which may be very different for each firm (Dunning 1977, 2000; Rugman, Verbeke 1998). However, it may also 
become increasingly important in terms of MNEs' ability to achieve global competitiveness (Rugman, Verbeke 2009), as MNEs' strategies interact with institutional factors and macroeconomic conditions to generate different levels of performance (Tallman, Yip 2009). This also implies that the location advantages of specific countries perceived by a particular MNE may shift over time, as exemplified in the international product life cycle.

The environmental conditions distinctive for the specific location of a subsidiary should be considered by the HQ management when tailoring a subsidiary's strategy and coordinating it to the network of the MNE (Filippov, Duysters 2012, p. 38). The importance of the local environment to a certain MNE will depend on its significance to this MNE's strategy and performance (Rugman et al. 2011, p. 254). If external conditions in a particular country are favorable for the MNE aims, the MNE's decisionmakers should be more willing to increase involvement in the certain subsidiary, leading to the fourth hypothesis:

Hypothesis 4: External environment specific factors are positively related to $H Q$ 's involvement.

On the other hand, changes in the environment should also be noticed by the subsidiary's management and taken into consideration in reference to new opportunities and threats facing the subsidiary (Filippov, Duysters 2012, p. 38). While a subsidiary has a particular amount of resources put at its disposal, external environment conditions may still foster the development of certain capabilities and facilitate access to certain specific resources, or threaten their future development. The idiosyncratic combination of a subsidiary's internal resources and resources accessed or gained thanks to favorable environmental conditions will determine a subsidiary role within the MNE (Rugman et al. 2011). In fact, Holm et al. (2005) provided empirical evidence for the impact of a host country's competitive environment on the development of the subsidiary's competence. This issue is also related to the concept of embeddedness of a subsidiary in the local market and in external networks; see e.g. Belderbos et al. (2001); Chen et al. (2004). Therefore, external conditions may influence the strategic maturity of a foreign subsidiary, which is why the fifth hypothesis is:

Hypothesis 5: External environment specific factors are positively related to the subsidiary's strategic maturity.

As mentioned before, it is assumed that the decisions and actions concerning the development of the foreign subsidiary's role are made in response to location specific conditions (Benito et al. 2003). This indicates that although it may be expected that external environment conditions exert 
influence on the development process of a foreign subsidiary role, this influence is rather indirect, as it is transferred by the decisions makers/action takers, and may be subject to their susceptibility to those conditions. Therefore, the sixth and seventh hypotheses are:

Hypothesis 6: The impact of external environment specific factors on the advancement of the subsidiary role in the MNE value chain is indirect, occurring through the $H Q$ 's involvement rather than directly.

Hypothesis 7: The impact of external environment specific factors on the advancement of the subsidiary role in the MNE value chain is indirect, occurring through the subsidiary's strategic maturity rather than directly.

\section{CLOSING COMMENTS}

The lists of potential indicators presented above can be changed, limited or in some parts built up as the result of further literature studies and external consultations. In the case of the use of composite measures, their internal consistency should be checked first. In particular, in order to measure the reliability of a psychometric instrument, Cronbach's alpha estimation could be executed. Additionally, the particular sets of indicators used in the model for each of the latent variables should be selected based on the statistical procedure encompassing factor analysis, discriminant validity and convergent validity tests.

Nevertheless, the foreign subsidiary role fulfilled within the value chain of an MNE may also depend on several factors other than the ones listed above. Therefore, in the empirical study researchers might find justification to check for additional factors covering, for example, foreign entry mode, ownership form, foreign investment age and cultural distance. The mentioned set of selected control variables, although they may be related to particular latent variables, are static and consequently would not change over time in relation to other observed entities. A proposition of such control variables is presented in Table 6.

As a result of technological, political and economic changes, relocation of value chain activities and coordination of these across borders is nowadays easier than it used to be (Dicken 2007; Mudabi 2008). Nowadays, a source of competitive advantage for contemporary MNEs is their ability to leverage distinct competencies of internationally dispersed subsidiaries (Dimitratos et al. 2014). Since few MNEs can rely on one or a few prime locations for their development, many of them build a wide network of 


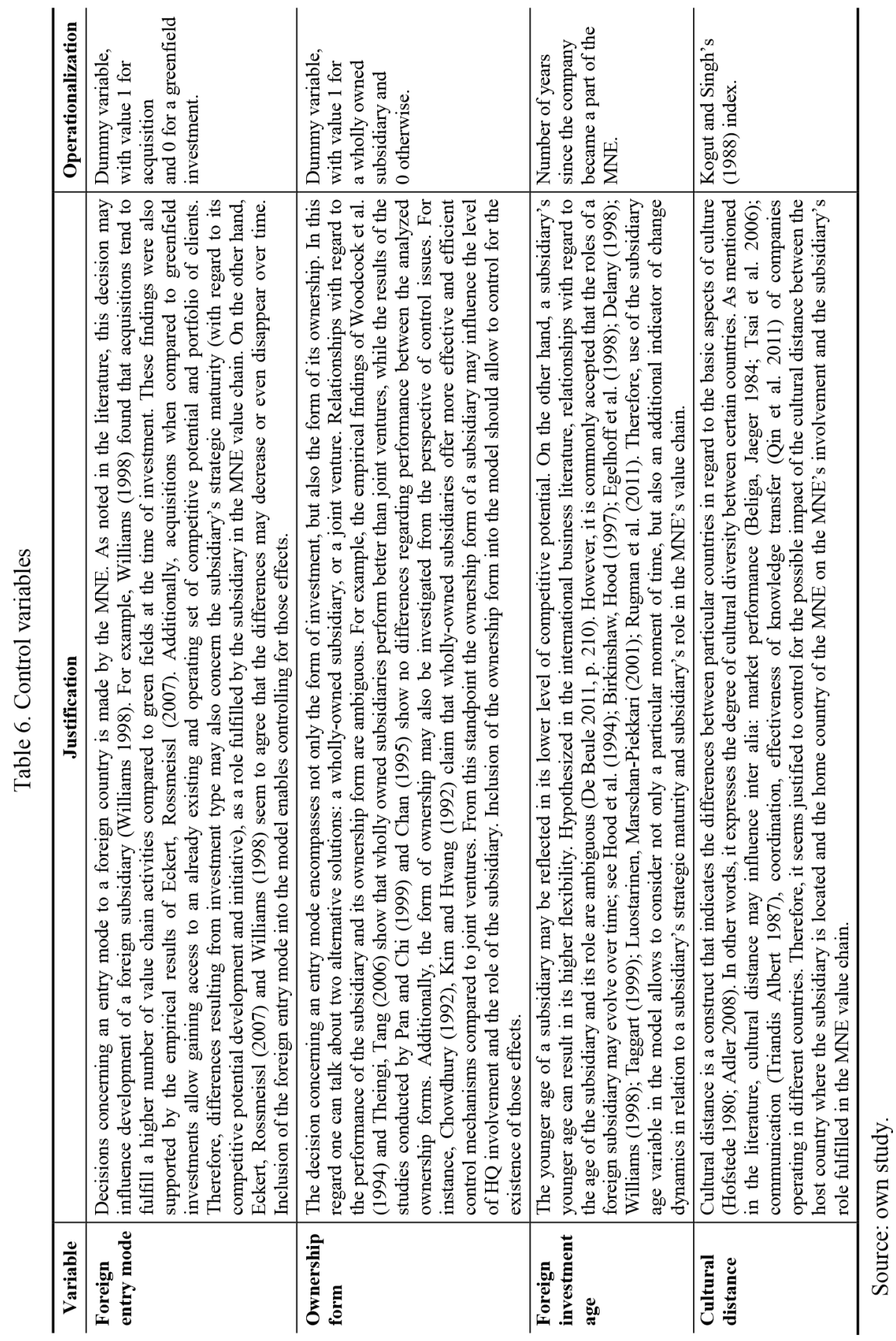




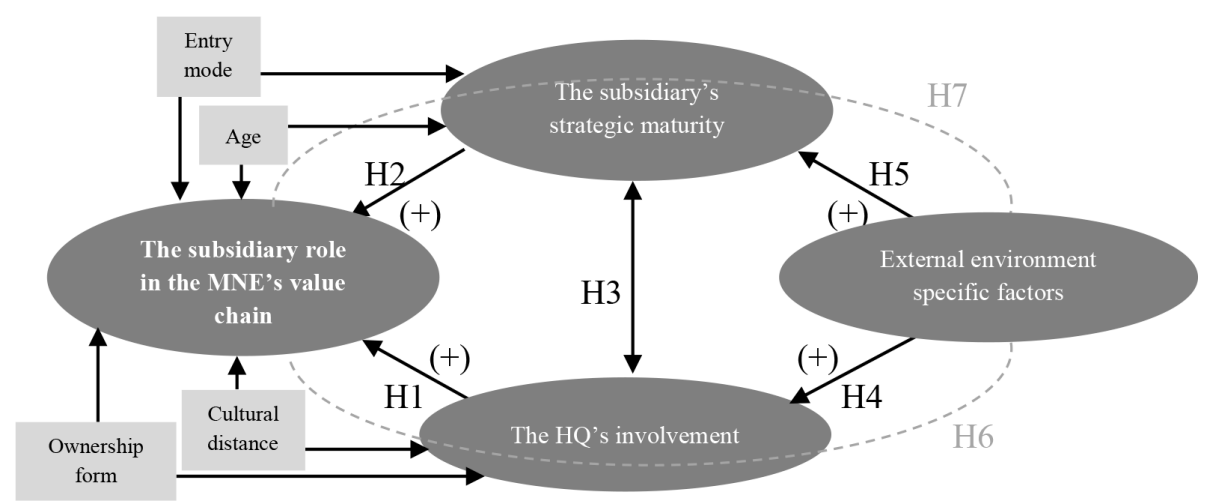

Figure 1. Proposed structural model

Source: own study.

subsidiaries, and further fine slice different activities in the subsidiaries (Birkinshaw, Pedersen 2009). As a result, many foreign subsidiaries specialize in relatively narrow sets of activities in an MNE value chain and perform different roles in it (Jensen, Pedersen 2011). Management of an MNE's portfolio locations worldwide and the distribution of its value-added activities across this portfolio is seen as an interesting and important configuration issue (Zaheer 2000; Westney, Zaheer 2009). Although the issue of MNEs' subsidiaries has been studied by international business scholars for several decades, there still exists a research gap, especially with regard to the roles they fulfill in the MNEs' value chains. The model presented in the paper constitutes a unique research proposal which is not only based on the existing theoretical achievements of business and management scholars, but also constitutes an expansion upon the methodological and cognitive dimensions of the studies so far.

\section{REFERENCES}

Ambos, B., Schlegelmilch, B. B., Innovation and control in a multinational firm: a comparison of political and contingency approaches, "Strategic Management Journal", vol. 28, Issue 5, pp. 437-486, 2007.

Ambos, T. C., Andersson, U., Birkinshaw, J. M., What are the consequences of initiativetaking in multinational subsidiaries?, "Journal of International Business Studies", vol. 41, issue 7, pp. 1099-1118, 2010.

Amit, R., Schoemaker, P., Strategic assets and organizational rents, "Strategic Management Journal", vol. 14, issue 1, pp. 33-46, 1993. 
Andersson, U., Forsgren, M., In search of centres of excellence: network embeddedness and subsidiary roles in multinational corporations, "Management International Review", vol. 40, issue 4, pp. 329-350, 2000.

Andersson, U., Forsgren, M., Holm, U., The strategic impact of external networks: subsidiary performance and competence development in the multinational corporation, "Strategic Management Journal", vol. 23, issue 11, pp. 979-996, 2002.

Andersson, U., Forsgren, M., Holm, U., Balancing subsidiary influence in the federative MNC: a business network view, "Journal of International Business Studies", vol. 38, issue 5, pp. 802-818, 2007.

Andersson, U., Johanson, J., International Business Enterprise [in:] Björkman, I., Forsgren, M., The Nature of the International Firm, pp. 33-49. Handelshöyskolens forlag, Copenhagen 1997.

Asakawa, K., Evolving headquarters-subsidiary dynamics in international R\&D: the case of Japanese multinationals, "R\&D Management", vol. 31, issue 1, pp. 1-14, 2001.

Barney, J., Firm resources and sustained competitive advantage, "Journal of Management", vol. 17, issue 1, pp. 99-120, 1991.

Bartett, C. A., Ghoshal, S., Managing Across Borders. The Transnational Solution. Harvard Business School Press, Boston 1989.

Bartlett, C. A., Ghoshal, S., Tap your subsidiaries for global reach, "Harvard Business Review", vol. 64, issue 6, pp. 87-94, 1986.

Belderbos, R., Campanelli, G. Fukao K., Backward vertical linkages of foreign manufacturing affiliates: evidence from Japanese multinationals, "World Development", vol. 29, issue 1, pp. 189-208, 2001.

Beliga, B. R., Jaeger, A., Multinational Corporations: Control Systems and Delegation Issues, "Journal of International Business Studies", vol. 15, issue 2, pp. 25-40, 1984.

Benito, G. R. G., Grøgaard, B., Narula, R., Environmental influences on MNE subsidiary roles: Economic integration and the Nordic countries, "Journal of International Business Studies", vol. 34, issue 5, pp. 443-456, 2003

Benito, G. R. G., Narula, R., Multinationals on the Periphery. Palgrave, London 2007.

Birkinshaw, J. M., Taking the initiative: value-adding strategies for Canadian Subsidiaries, "Business Quarterly", vol. 59, issue 4, pp. 97-102, 1995.

Birkinshaw, J. M., How multinational subsidiary mandates are gained and lost, "Journal of International Business Studies", vol. 27, issue 3, pp. 467-495, 1996.

Birkinshaw, J. M., Entrepreneurship in multinational corporations: The characteristics of subsidiary initiatives, "Strategic Management Journal", vol. 18, issue 3, pp. 207-29, 1997.

Birkinshaw, J. M., Entrepreneurship in Global Firms. Sage, London 2000.

Birkinshaw, J. M., Hood, N., An empirical study of development processes in foreign-owned subsidiaries in Canada and Scotland, "Management International Review", vol. 37, issue 4, pp. 339-364, 1997.

Birkinshaw, J. M., Hood, N., Multinational subsidiary evolution: capability and charter change in foreign-owned subsidiary companies, "Academy of Management Review", vol. 23, issue 4, pp. 773-795, 1998.

Birkinshaw, J. M., Hood, N., Jonsson, S., Building Firm-specific Advantages in Multinational Corporations: The Role of Subsidiary Initiative, "Strategic Management Journal", vol. 19, issue 3, pp. 221-242, 1998. 
Birkinshaw, J. M., Pedersen, T., Strategy and Management in MNE Subsidiaries [in:] Rugman, M. A. (ed.), The Oxford Handbook of International Business, pp. 367-388. Oxford University Press, New York 2009.

Birkinshaw, J. M., Toulan, O., Arnold, D., Global account management in multinational corporations: Theory and evidence, "Journal of International Business Studies", vol. 32, issue 2, pp. 321-348, 2001.

Bishop, P., Crookell, H. H., Specialization in Canadian subsidiaries [in:] McFetridge, G. D. (ed.), Canadian Industry in Transition, pp. 305-386. University of Toronto Press, Toronto 1986.

Boehe, D. M., Product development in emerging market subsidiaries - the influence of autonomy and internal markets on subsidiary roles, "International Journal of Innovation and Technology Management”, vol. 5, issue 1, pp. 29-53, 2008.

Brandt, W. K., Hulbert, J. M., Headquarters guidance in marketing strategy in the multinational subsidiary, "Columbia Journal of World Business", vol. 12, issue 4, pp. 7-14, 1977.

Cantwell, J., Mudambi, R., MNE competence-creating subsidiary mandates, "Strategic Management Journal", vol. 26, issue 12, pp. 1109-1128, 2005.

Chan, P. S., International joint ventures vs. wholly owned subsidiaries, "Multinational Business Review", vol. 3, issue 1, pp. 37-44, 1995.

Chen, T-J., Chen, H., Rku, Y. H., Foreign direct investment and local linkages, "Journal of International Business Studies", vol. 35, issue 4, pp. 320-333, 2004.

Chowdhury, J., Performance of international joint ventures and wholly owned subsidiaries, "Management International Review", vol. 32, issue 2, pp. 105-113, 1992.

Cox, E. P., The optimal number of response alternatives for a scale: a review, "Journal of Marketing Research", vol. 17, issue 4, pp. 407-442, 1980.

Cray, D., Control and coordination in multinational corporations, "Journal of International Business Studies", vol. 15, issue 2, pp. 85-98, 1984.

Crookell, H. H., Specialization and international competitiveness [in:] Etemad, H., SeguinDulude, L. (eds.), Managing the Multinational Subsidiary, pp. 102-111. Croom Helm, London 1986.

Crookell, H. H., Morrison, A. J., Subsidiary strategy in a free trade environment, "Business Quarterly", vol. 55, issue 2, pp. 33-39, 1990.

Cyrson, E., Nowy paradygmat strategii konkurencji [New paradigm for competition strategy] [in:] Skawińska, E. (ed.), Konkurencyjność przedsiębiorstw: nowe podejście [The competitiveness of enterprises: A new approach], pp. 13-54, .PWN, Warszawa-Poznań 2002.

D'Cruz, J. R., Strategic management of subsidiaries [in:] Etemad, H., Dulude, L. (eds.), Managing the Multinational Subsidiary, pp. 75-89. St. Martin's Press, 1986.

Dacin, M. T., Ventresca, M. J., Beal, B. D., The embeddedness of organizations: Dialogue and directions, "Journal of Management", vol. 25, issue 3, pp. 317-356, 1999.

De Beule, F., Subsidiary strategic evolution in China [in:] Verbeke, A., Tavares-Lehmann, T. A., Van Tulder, R. (eds.), Entrepreneurship in the Global Firm, pp. 199-222. Emerald Group Publishing Limited, 2011.

Delany, E., Strategic development of multinational subsidiaries in Ireland, [in:] Birkinshaw, M. J., Hood, N. (eds.), Multinational Corporate Evolution and Subsidiary Development, pp. 239-267. Macmillan, Houndmills 1998. 
Delany, E., Strategic development of the multinational subsidiary through subsidiary initiative-taking, "Long Range Planning", vol. 33, issue 2, pp. 220-244, 2000.

Dicken, P., Global Shift: Mapping the Changing Contours of the World Economy. Sage, London 2007.

Dimitratos, P., Liouka, I., Young, S., A Missing Operationalization: Entrepreneurial Competencies in Multinational Enterprise Subsidiaries, "Long Range Planning", vol. 47, issue 1-2, pp. 64-75, 2014.

Dörrenbächer, Ch., Gammelgaard, J., Subsidiary role development: The effect of micropolitical headquarters-subsidiary negotiations on the product, market and value-added scope of foreign-owned subsidiaries, "Journal of International Management", vol. 12, issue 3, pp. 266-283, 2006.

Dunning, J. H., Trade, Location of Economic Activity and the MNE: A Search for an Eclectic Approach [in:] Ohline, B., Hesselborn, O. P., Wijkman, M. P. (eds.), The International Allocation of Economic Activity, pp. 395-418. Macmillan, London 1977.

Dunning, J. H., The Eclectic Paradigm as an Envelope for Economic and Business Theories of MNE Activity, "International Business Review", vol. 9, issue 2, pp. 163-190, 2000.

Dunning, J. H., Robson, P., Multinationals and the European Community. Basil Blackwell, Oxford 1988.

Eckert, S., Rossmeissl, F., Local Heroes, Regional Champions or Global Mandates? Empirical Evidence on the Dynamics of German MNC Subsidiary Roles in Central Europe, "Journal of East-West Business", vol. 13, issue 2, pp. 191-218, 2007.

Egelhoff, W.G., Gorman, L., McCormick, S., Using technology as a path to subsidiary development [in:] Birkinshaw, M. J., Hood, N. (eds.), Multinational corporate evolution and subsidiary development, pp. 213-238. Macmillan, Houndmills 1998.

Enright, M. J., Subramanian, V., An Organizing Framework for MNC Subsidiary Typologies, "Management International Review", vol. 47, issue 6, pp. 895-924, 2007.

Filippaios, F., Papanastassiou, M., US Outward Foreign Direct Investment in the European Union and the Implementation of the Single Market: Empirical Evidence from a Cohesive Framework, "Journal of Common Market Studies", vol. 46, issue 5, pp. 969-1000, 2008.

Filippov, S., Duysters, G., Evolving Subsidiary Roles and Regional Economic Integration in Europe, "Transformations in Business \& Economics", vol. 11, issue 25, pp. 35-53, 2012.

Ford, S., Strange, R., Where Do Japanese Manufacturing Firms Invest within Europe, and Why?, "Transnational Corporations", vol. 8, issue 1, pp. 117-142, 1999.

Forsgren, M., Johanson, J., Sharma, D., Development of MNC Centres of Excellence [in:] Holm, U., Pedersen, T. (eds.), The Emergence and Impact of MNC Centres of Excellence, pp. 45-67. Palgrave Macmillan, London 2000.

Forsgren, M., Pedersen, T., Centres of Excellence in Multinational Companies: The Case of Denmark [in:] Birkinshaw, M. J., Hood, N. (eds.), Multinational Corporate Evolution and Subsidiary Development, pp. 141-161. Macmillan, Houndmills 1998.

Forsgren, M., Pedersen, T., Foss, N. J., Accounting for the strengths of MNC subsidiaries: The case of foreign-owned firms in Denmark, "International Business Review", vol. 8, issue 2, pp. 181-196, 1999. 
Fratocchi, L., Holm, U., Centres of excellence in the international firm [in:] Birkinshaw, M. J., Hood, N. (eds.), Multinational Corporate Evolution and Subsidiary Development, pp. 189-209. Macmillan, Houndmills 1998.

Frost, T., Birkinshaw, J. M., Ensign, S., Centres of excellence in multinational corporations, “Strategic Management Journal”, vol. 23, issue 11, pp. 997-1015, 2002.

Furu, P., Drivers of Competence Development in Different Types of Multinational R\&D Subsidiaries, "Scandinavian Journal of Management", vol. 17, issue 1, pp. 133-149, 2001.

Ghoshal, S., The Innovative Multinational: A Differentiated Network of Organizational Roles and Management Processes, Harvard Business School, Boston 1986.

Ghoshal, S., Bartlett, C., The multinational corporation as an interorganizational network, “Academy of Management Review”, vol. 15, issue 4, pp. 603-625, 1991.

Ghoshal, S., Nohria, H., Internal differentiation within multinational corporations, "Strategic Management Journal", vol. 10, issue 4, pp. 323-337, 1989.

Ghoshal, S., Nohria, N., The Differentiated MNC: Organizing Multinational Corporation for Value Creation. Jossey-Bass, San Francisco 1997.

Gupta, A. K., Govindaraian, V., Knowledge flows and the structure of control within multinational corporations, "Academy of Management Review", vol. 16, issue 4, pp. 768-792, 1991.

Harzing, A. W., Noorderhaven, N. G., Knowledge flows in MNCs: An empirical test and extension of Gupta and Govindarajan's typology of subsidiary roles, "International Business Review", vol. 15, issue 3, pp. 195-214, 2006.

Hedlund, G., Rolander, D., Action in Heterarchies - New Approaches to Managing the MNC [in:] Bartlett, C., Doz, Y., Hedlund, G. (eds.), Managing the Global Firm, pp. 15-46. Routledge, London 1990.

Hennart, J. F., Theories of the Multinational Enterprise, [in:] Rugman, M. A. (ed.), The Oxford Handbook of International Business, pp. 125-145. Oxford University Press, New York 2009.

Holm, U., Holmström, C., Sharma, D., Competence Development through Business Relationships or Competitive Environment: Subsidiary Impact on MNC Competitive Advantage, "Management International Review", vol. 45, issue 2, pp. 197-218, 2005.

Holm, U., Pedersen, T. (eds.), The Emergence and Impact of MNC Centres of Excellence. Palgrave Macmillan, London 2000.

Hood, N., Young, S., Lai, D., Strategic evolution within Japanese manufacturing plants in Europe: UK evidence, "International Business Review", vol. 3, issue 2, pp. 97-122, 1994.

Jensen, P., Pedersen, T., The economic geography of offshoring: the fit between activities and local context, "Journal of Management Studies", vol. 48, issue 2, pp. 352-372, 2011.

Kim, W. C., Hwang, P., Global strategy and multinationals' entry mode choice, "Journal of International Business Studies”, vol. 23, issue 1, pp. 29-53, 1992.

Kindleberger, C., European Integration and the International Corporation, "Columbia Journal of World Business", vol. 1, issue 1, pp. 65-73, 1966.

Lomi, A., Larsen, E. R., Interacting Locally and Evolving Globally: A Computational Approach to the Dynamics of Organizational Populations, "Academy of Management Journal", vol. 39, issue 4, pp. 1287-1321, 1996. 
Lomi, A., Pettison, P. E., Manufacturing Relations: An Empirical Study of the Organization of Production across Multiple Networks, "Organization Science", vol. 17, issue 3, pp. 313-332, 2006.

Lorenzoni, G., Baden-Fuller, C., Creating a Strategic Center to Manage a Web of Partners, "California Management Review", vol. 37, issue 3, pp. 146-163, 1995.

Luostarinen, R., Marschan-Piekkari, R., Strategic evolution of foreign-owned subsidiaries in a host country: A conceptual framework [in:] Taggart, H. J., Berry, M., McDermott, M., (eds.), Multinationals in a new era: international strategy and management, pp. 180-193. Palgrave Macmillan, Houndmills 2001.

Madhok, A., Cost, value and foreign market entry mode: The transaction and the firm, "Strategic Management Journal", vol. 18, issue 1, pp. 33-69, 1997.

Manolopoulos, D., A Systematic Review of the Literature and Theoretical Analysis of Subsidiary Roles, "Journal of Transnational Management", vol. 13, issue 1, pp. 23-57, 2008.

Manolopoulos, D., Papanastassiou, M., Pearce, R., Technology sourcing in multinational enterprises and the roles of subsidiaries: an empirical investigation, "International Business Review", vol. 14, issue 3, pp. 249-267, 2005.

Martinez, J. I., Jarillo, J. C., Different roles for subsidiaries: the case of multinational corporations in Spain, "Strategic Management Journal”, vol. 11, issue 7, pp. 501-512, 1990.

McEvily, B., Zaheer, A., Bridging ties: A source of firm heterogeneity in competitive capabilities, "Strategic Management Journal”, vol. 20, issue 12, pp. 1133-1156, 1999.

Mudambi, R., Location, control and innovation in knowledge-intensive industries, "Journal of Economic Geography", vol. 8, issue 5, pp. 699-725, 2008.

Mudambi, R., Navarra, P., Is knowledge power? Knowledge flows, subsidiary power and rentseeking within MNCs, "Journal of International Business Studies", vol. 35, issue 5, pp. 385-406, 2004.

Nachum, L., Economic Geography and the Location of TNCs: Financial and Professional Service FDI to the USA, "Journal of International Business Studies", vol. 31, issue 3, pp. 367-385, 2000.

Nobel, R., Birkinshaw, J. M., Patterns of control and communication in international research and development units, "Strategic Management Journal", vol. 19, issue 5, pp. 479-498, 1998.

Nohria, N., Ghoshal, S., Differentiated fit and shared values: alternatives for managing headquarters-subsidiary relations, "Strategic Management Journal", vol. 15, issue 6, pp. 491-502, 1994.

OECD, OECD Guidelines for Multinational Enterprises, OECD, Paris 2008.

Pan, Y., Chi, P. S. K., Financial performance and survival of multinational corporations in China, "Strategic Management Journal", vol. 20, issue 4, pp. 359-374, 1999.

Penrose, E. T., The Theory of the Growth of the Firm. Oxford University Press, New York 1959.

Pfeffer, J., Salancik, G. R., The External Control of Organizations: A Resource Dependence Perspective. Harper \& Row, New York 1978. 
Picard, J., Organizational structures and integrative devices in European multinational corporations, "Columbia Journal of World Business", vol. 15, issue 1, pp. 30-35, 1980.

Porter, M., The competitive advantage of nations. The Free Press, New York 1990.

Porter, M. E., Competitive Advantage: Creating and Sustaining Superior Performance. The Free Press, New York 1985.

Prahalad, C. K., Doz, Y. L., An approach to strategic control in MNCs, "Sloan Management Review", vol. 22, issue 4, pp. 5-13, 1981.

Prahalad, C. K., Hamel, G., The Core Competence of the Corporation, "Harvard Business Review", vol. 68, issue 3, pp. 79-91, 1990.

Qin, C., Ramburuth, P., Wang, Y., A Conceptual Model of Cultural Distance, MNC Subsidiary Roles, and Knowledge Transfer in China-Based Subsidiaries, "Organizations and Markets in Emerging Economies", vol. 2, issue 2, pp. 8-27, 2011.

Rank, O., Rollentypologien für Tochtergesellschaften. Ansätze und strategische Implikationen für das internationale Management [Typologies of subsidiary roles. Approaches and strategic implications for international management], Döbler \& Rössler, Stuttgart 2000.

Rugman, A., Verbeke, A., Subsidiary-specific advantages in multinational enterprises, "Strategic Management Journal”, vol. 22, issue 3, pp. 237-50, 2001.

Rugman, A., Verbeke, A., Extending the theory of the multinational enterprise: Internalization and strategic management perspectives, "Journal of International Business Studies", vol. 34, issue 2, pp. 125-37, 2003.

Rugman, A., Verbeke, A., Yuan, W., Re-conceptualizing Bartlett and Ghoshal's Classification of National Subsidiary Roles in the Multinational Enterprise, "Journal of Management Studies", vol. 48, issue 2, pp. 253-277, 2011.

Rugman, A. M., Verbeke, A., Multinational Enterprise and Public Policy, "Journal of International Business Studies”, vol. 29, issue 1, pp. 115-136, 1998.

Rugman, A. M., Verbeke, A., Location, Competitiveness and the Multinational Enterprise, [in:] Rugman, M. A. (ed.), The Oxford Handbook of International Business, pp. 146-180. Oxford University Press, New York 2009.

Salgado, O., Barriers to the Accomplishment of a Subsidiary's Strategic Role: How Location and Corporate Networks Influence Subsidiary Performance, RAC, vol. 15, pp. 261-282, 2011.

Spanos, Y. E., Lioukas, S., An examination into the causal logic of rent generation: contrasting Porter's competitive strategy framework and the resource-based perspective, "Strategic Management Journal", vol. 22, issue 10, pp. 907-934, 2001.

Surlemont, B., A Typology of centres within multinational corporations: an empirical investigation [in:] Birkinshaw, M. J., Hood, N. (eds.), Multinational corporate evolution and subsidiary development, pp. 162-188. Macmillan, Houndmills 1998.

Taggart, J. H., Autonomy and procedural justice: A framework for evaluating subsidiary strategy, "Journal of International Business Strategies", vol. 28, issue 1, pp. 51-76, 1997.

Taggart, J. H., Identification and development of strategy at subsidiary level [in:] Birkinshaw, M. J., Hood, N. (eds.), Multinational corporate evolution and subsidiary development, pp. 23-49. Macmillan, Houndmills 1998. 
Taggart, J. H., US MNC subsidiaries in the UK: Characteristics and strategic role [in:] Burton, F., Chapman, M., Cross, A. (eds.), International Business Organization, pp. 29-46. Macmillan, Houndmills 1999.

Tallman, S. B., Yip G. S., Strategy and the Multinational Enterprise [in:] Rugman, M. A. (ed.), The Oxford Handbook of International Business, pp. 307-340. Oxford University Press, New York 2009.

Theingi, H., Tang, J. C. S., The effect of a firm's specific characteristics and entry mode on its performance: Thailand's electronic Industry, "Asia Pacific Journal of Economics and Business", vol. 10, issue 2, pp. 36-53, 2006.

Triandis, H. C., Albert, R. D., Cross-cultural perspectives [in:] Jablin, M. F., Putnam, L. L., Roberts, H. K., Porter, W. L. (eds.), Handbook of Organizational Communication: An Interdisciplinary Perspective, pp. 264-295. Sage, Newbury Park, CA 1987.

Tsai, M.-T., Yu, M.-Ch., Lee, K.-W., Relationships between subsidiary strategic roles and organizational configuration: The case of Taiwanese multinational companies, "International Journal of Commerce \& Management", vol. 16, issue 1, pp. 3-14, 2006.

Wernerfelt, B., A resource-based view of the firm, "Strategic Management Journal", vol. 5, issue 2, pp. 171-180, 1984.

Westney, D. E., Zaheer, S., The Multinational Enterprise as an Organization [in:] Rugman, M. A. (ed.), The Oxford Handbook of International Business, pp. 341-366. Oxford University Press, New York 2009.

White, R. E., Poynter, T. A., Strategies for foreign-owned subsidiaries in Canada, "Business Quarterly", vol. 49, issue 2, pp. 59-69, 1984.

Williams, D., The development of foreign-owned manufacturing subsidiaries: Some empirical evidence, "European Business Review", vol. 98, issue 5, pp. 282-286, 1998.

Woodcock, P. C., Beamish, P. W., Makino, S., Ownership-based entry mode strategies and international performance, "Journal of International Business Studies", vol. 25, issue 2, pp. 253-373, 1994.

Yamawaki, H., Locational Decisions of Japanese Multinational Firms in European Manufacturing Industries [in:] Hughes, K. (ed.), European Competitiveness, pp. 11-28. Cambridge University Press, Cambridge 1993.

Zaheer, S., Time-Zone Economies and Managerial Work in a Global World [in:] Earley, C. P., Singh, H. (eds.), Innovations in International and Cross-Cultural Management, pp. 339-353. Sage, Thousand Oaks 2000.

Zhou, C., Frost, T. S., R\&D Co-practice and 'Reverse' Knowledge Integration in Multinational Firms, "Journal of International Business Studies", vol. 36, issue 6, pp. 676-687, 2005.

Received: December 2017

Acknowledgement: The project has been financed by the National Science Centre Poland, decision no. DEC-2013/09/D/HS4/02720. 